\title{
Pre-service Teachers' Beliefs: Impact of Training in Universal Design for Learning
}

\author{
Christopher S. Lanterman and Karen Applequist \\ Northern Arizona University
}

\begin{abstract}
Seventy-seven pre-service teachers enrolled in an introductory special education course completed a questionnaire on their beliefs about learning, teaching, and disability, before and after completing one of two randomly assigned training modules on Universal Design for Learning (UDL). Module A presented UDL as a strategy for meeting the specific needs of students with disabilities in a general education setting. Module $B$ presented UDL as a framework to support all learners in the general education classroom through the creation of communities of learners. The Beliefs About Learning, Teaching, and Disability Questionnaire (BLTDQ) was administered with five subscales rated on a 6-point Likert-type scale that measure pre-service teachers' beliefs about learning and teaching, as representative of their epistemological beliefs, beliefs about disability (from pathognomonic to interventionist) and the role of the teacher in the general education classroom. Analyses of these results suggest that a significant change toward interventionist beliefs about learning, teaching, and disability occurred for participants who completed either module on UDL. Additionally, a small to moderate, positive relationship was identified between pre-service teachers' beliefs about disability and their epistemological beliefs, with the strength of this relationship increasing following their training in UDL. These findings suggest that training in UDL can have a powerful and positive impact on pre-service teachers' interventionist epistemological beliefs and beliefs about disability. Shifts toward interventionist beliefs are more likely to result in teaching practices that are more supportive of students with disabilities in general education classrooms. Implications for teacher preparation and study limitations are also discussed.
\end{abstract}


In the United States during the 2015-2016 school year, nearly 63\% (62.7\%) of all students receiving special education services, ages 6 through 21 , were served in the general education classroom for $80 \%$ of the day, or more (U.S. Department of Education, 2017). This percentage is up from nearly 54\% (53.6\%) in 2005 (U.S. Department of Education, 2007). Students with disabilities are being placed in the general education classroom for the majority of the school day at an increasing rate. Such increases are occurring against the backdrop of ongoing debates about the distinction between the least restrictive environment and inclusion (Artiles \& Kozleski, 2016) and about a clear definition of inclusion (Ainscow, Dyson, \& Weiner, 2012; Crockett, 2014). Though Crockett (2014) noted that no consistent definition of inclusion has been established, various definitions of inclusion have been proffered in the literature. For example, Kauffman, Anastasiou, Badar, Travers, and Wiley (2016) suggested that inclusive education should occur in the general education classroom if that is the learning environment in which students are most likely to learn the skills necessary for future success. Artiles and Kozleski (2016) suggested that inclusion is the enhancement of "educational access, participation, and outcomes for students from all backgrounds, independent of any form of difference that students purportedly embody" (p. 9). Fundamental discourses on beliefs about disability and inclusion may be at the heart of these differences.

\section{Teachers' Beliefs About Disability and About Teaching Students with Disabilities}

Several major factors seem to impact teacher beliefs about disability, about students with disabilities, and about teaching students with disabilities in inclusive settings. These factors include teachers' senses of preparation, particularly related to teacher preparation (e.g., Ajuwon et al., 2012; Cook, 2002; Scruggs \& Mastropieri, 1996), prior experiences with persons who have disabilities (e.g., Alghazo, Dodeen, \& Algaryouti, 2003; Forlin \& Chambers, 2011), beliefs about disability, including perceived severity of a disability (e.g., Cook \& Cameron, 2010; Jordan, Schwartz, \& McGhie-Richmond, 2009; McHatton \& Parker, 2013), and teacher self-efficacy (e.g., Dunst \& Bruder, 2013; Silverman, 2007).

Along with the factors affecting teachers' beliefs noted in these studies, some research focused on the relationship between teachers' beliefs about knowledge and learning and their beliefs about disability and teaching students with disabilities in general education settings (Glenn, 2007; Jordan \& Stanovich, 2003; Sheehy, Budiyanto, \& Rofiah, 2017; Silverman, 2007). Silverman (2007) described epistemological beliefs as existing along a continuum from naive to high level. At the naive end of this continuum are beliefs in which knowledge consists of discrete facts, learning occurs quickly or not at all, and the ability to acquire knowledge is endowed at birth. At the other end of the continuum are beliefs that knowledge is complex, learning is improvable and gradual, and that learners can be active constructors of knowledge (Schraw, 2013; Silverman, 2007). Epistemological beliefs are closely aligned with beliefs about ability and the variable role of effort. Dweck (1999) identifies entity beliefs as those that suggest that ability is fixed, aligning with the naïve epistemological beliefs. Incremental beliefs are those that suggest that learning can occur from good teaching, study, and practice, aligning with high level epistemological beliefs (Dweck, 1999). 
Silverman (2007) reported on a study comparing epistemological beliefs and attitudes toward inclusion among 71 pre-service teachers. Silverman found a statistically significant association between participants' high-level epistemological beliefs and attitudes toward including students with disabilities. Sheehy et al. (2017) conducted a study among 267 Indonesian teachers from regular, special, and inclusive schools to evaluate the degree to which epistemological beliefs would predict the teachers' beliefs about inclusive education. They developed and administered a 40-item questionnaire with items relating to beliefs about models of learning (i.e., constructivist, social constructivist, and behaviourist), beliefs about the nature of ability, beliefs about happiness, and the use of manual signing as a proxy for beliefs about the stigmatization of difference. Study results indicated that teachers' epistemological beliefs were highly predictive of their beliefs about inclusive education.

A series of studies conducted by Jordan and colleagues (Jordan, Glenn, \& McGhieRichmond, 2010; Jordan, Lindsay, \& Stanovich, 1997; Jordan et al., 2009; Jordan \& Stanovich, 2003; Stanovich \& Jordan, 1998; see also Jordan, 2018a, 2018b in this issue for a recent summary) reported on their exploration of teacher beliefs about disability and the role of the teacher in supporting students with disabilities in the general education classroom. The Supporting Effective Teaching (SET) project reported on the development and implementation of the Pathognomonic-Interventionist (P-I) Interview, a questionnaire that sought to uncover such a relationship. Jordan et al. (1997) found that teachers are less likely to take responsibility for their students with disabilities when they believe that disability is a fixed property of the student. Jordan et al. (1997) classified such beliefs as pathognomonic. Conversely, teachers are more likely to engage positively and take responsibility for students with disabilities when they hold interventionist beliefs, whereby disability is seen as a function of the interaction between an impairment and the learning environment (Jordan et al., 1997; Jordan et al., 2010).

Glenn (2007) investigated the relationship between entity-increment (E-I) beliefs about ability and P-I beliefs about disability among 120 pre-service and 66 practising teachers in Canada. Among the 186 participants in her study, Glenn sampled data from PI interviews of 36 teachers who had also participated in the SET project. Using the Beliefs About Learning and Teaching Questionnaire (BLTQ; Glenn, 2007, 2018; Jordan, Washington, Schwartz, \& Ahmed, 2005), Glenn found that incremental beliefs about ability were highly correlated with participant interventionist beliefs about disability. Though a significant correlation between epistemological beliefs, beliefs about disability, and teaching practices was not identified, Glenn's findings offered potential for further research into these relationships.

The research conducted by Jordan and colleagues suggests that one potential avenue for enhancing teachers' interactions and sense of responsibility for their students could be to shift teachers' beliefs from pathognomonic to interventionist beliefs about disability. At the heart of this issue is locating an approach that might facilitate such a shift, particularly since teacher beliefs may be difficult to change (Pajares, 1992; Richardson, 1996). 


\section{Universal Design for Learning}

The practice of universal design for learning (UDL) is a promising element of today's education (Baglieri, Valle, Connor, \& Gallagher, 2011; Katz \& Sokal, 2016; Turnbull, Turnbull, Wehmeyer, \& Shogren, 2016). UDL suggests that flexible learning environments facilitate access to the general education curriculum for all learners, including students with disabilities (Meyer, Rose, \& Gordon, 2014). UDL has been recognized as a scientifically valid approach for instructional practice (Higher Education Opportunity Act, 2008).

UDL is characterized by three major principles and nine supporting guidelines reflecting flexibility in approaches to engaging students within the curriculum, providing information, and determining student learning. These three principles are recognized as (a) multiple means of engagement, (b) multiple means of representation, and (c) multiple means of action and expression. In its entirety, UDL is a framework that is grounded in brain research and the ways in which different functions of the neural networks interface with instructional and assessment approaches. Each of the three principles recognizes that no single approach will work for everyone, so the universality of these concepts is in their flexibility and intention to meet the needs of the broadest possible group of users (Meyer et al., 2014).

The literature on UDL suggests that it promotes access to the general education curriculum for students with disabilities (Abell, Jung, \& Taylor, 2011; McGuire, Scott, \& Shaw, 2006), to meet the needs of culturally and linguistically diverse learners (ChitaTegmark, Gravel, Serpa, Domings, \& Rose, 2012), to support Response To Intervention (RTI; Basham, Israel, Graden, Poth, \& Winston, 2010), and to ground the development of inclusive lesson plans in pre-service teacher preparation (Courey, Tappe, Siker, \& LePage, 2013; Spooner, Baker, Harris, Ahlgrim-Delzell, \& Browder, 2007). UDL has also been framed as a means for reconceptualizing the least restrictive environment from one of exclusion to one of inclusion (Gabel, 2006), reforming the general education classroom to promote community and embrace differences (Baglieri, 2017), inviting critical reflection on the meaning of full inclusion (Routel, 2013), eliminating segregated systems for general and special education (Baglieri et al., 2011), and positioning students with disabilities at the centre of the curriculum, rather than as "failed exceptions to the rule" (Mitchell, Snyder, \& Ware, 2014, p. 305).

Thus, UDL appears to hold great promise as an instructional framework for teaching students with and without disabilities. In fact, Capp (2017) conducted a meta-analysis of 18 empirical studies involving the application of UDL for improving learning processes and student learning outcomes. Capp's analysis supports the assertion that UDL can improve learning processes, though it has not yet been shown to improve student learning outcomes. Additionally, the intention of UDL to support all learners, not just those with disabilities, continues to be elusive; and its implementation is variable across schools, districts, and states (Ralabate et al., 2012; Vitelli, 2015). As Edyburn (2010) argued, UDL is a construct without a clear definition.

Still, the broad support for UDL as an educational framework and the identified relationship between beliefs about disability and teachers' interactions with students who have disabilities suggest the value of exploring the ways in which training in UDL for pre-service teachers might impact their beliefs about learning, teaching, and disability. 
Further, in order to understand whether the way in which UDL was presented would differentially impact pre-service teachers' beliefs about learning, teaching, and disability, this study presented UDL through two discrete online modules, Module A and Module B. Each module reflected different epistemological beliefs about learning and teaching students with disabilities. Module A focused on disability as an innate and immutable characteristic in need of specialized instruction, suggesting entity and pathognomonic beliefs (Glenn, 2007). Module B emphasized that disability is constructed through an interaction between an individual's impairment and her environment (Wilson, 2017) and that the design of learning environments can allow for all students to become expert learners, reflecting incremental and interventionist beliefs (Myer et al., 2014). Therefore, this study addressed the research questions: (a) Is there a significant difference in preservice teachers' beliefs about learning, teaching, and disability between participants who completed Module A and those who completed Module B? and (b) Is there a relationship between pre-service teachers' epistemological beliefs and their beliefs about disability?

\section{Method}

Before and after completing the study intervention, study participants completed the Beliefs About Learning, Teaching, and Disability Questionnaire (BLTDQ) adapted from Glenn's (2007) Beliefs About Learning and Teaching Questionnaire (BLTQ). Participants were randomly assigned to one of the two online instructional modules on UDL, Module A and Module B, which constituted the intervention for this study.

\section{Intervention}

All teacher candidates enrolled in sections of an introductory course in special education at a mid-sized, 4-year public university in the southwestern United States were required to complete one or the other of the two instructional modules. The introductory course is required of all teacher candidates in early childhood education, elementary education, and elementary and special education degree programs. The instructional modules supplanted the traditional classroom lecture on UDL, and were presumed to constitute the teacher candidates' first exposure to the topic of UDL in this course.

Theoretical grounding. The development of the intervention modules was premised on two underlying conceptions of disability. Module A situated disability as an innate characteristic of an individual requiring individualized interventions. This view of disability is widely accepted as the core of special education services and supports through the application of the individualized education program (Danforth, Taff, \& Ferguson, 2006). This view of disability is sometimes referenced as a medical or deficit model of disability (Jordan et al., 1997; Wilson, 2017). By contrast, Module B framed disability as an important dimension of diversity and more a function of the learning environment than the student's impairment. These conceptions of disability have been variously called the social model of disability (Baglieri et al., 2011) or a social interpretation of disability (Wilson, 2017). Two outside reviewers evaluated the content of each module to determine their content validity. One reviewer was a former educator and administrator with special education experience and knowledge of UDL (Reviewer 1). The second reviewer had extensive knowledge of the social model of disability, UDL, 
and the field of disability studies (Reviewer 2). Both reviewers were employees of the authors' institution. Initial feedback from Reviewer 1 suggested potential for greater differentiation between the content of the modules, while Reviewer 2 noted sufficient differentiation. In response to comments by Reviewer 1, additional content and references were added to Module A to emphasize the use of UDL as an accommodation specifically for students with disabilities within general education classrooms and to reinforce the concept of disability as a biological limitation, notwithstanding the more liberatory intent of UDL. No modifications were made to Module B. Descriptions and examples of module contents are described in Figure 1 and the following section.

Figure 1. List of Videos Referenced Within Module A and Module B

\begin{tabular}{|c|c|}
\hline Ile A & Module B \\
\hline $\begin{array}{l}\text { UDL At A Glance } \quad(4: 36) \\
\text { https://www.youtube.com/watch?v=bDvK } \\
\text { nY0g6e4 }\end{array}$ & $\begin{array}{l}\text { Inclusion, Belonging, and the Disability } \\
\text { Revolution } \\
\text { https://www.youtube.com/watch?v=VAM9nh } \\
\text { 8WC-8 }\end{array}$ \\
\hline $\begin{array}{l}\text { The Myth of Average } \\
\text { https://www.youtube.com/watch?v=4eBm } \\
\text { yttcfU4 } \\
\text { UDLPrinciples and Practices }\end{array}$ & $\begin{array}{l}\text { UDL At A Glance } \\
\text { https://www.youtube.com/watch?v=bDvKnY0 } \\
\text { g6e4 }\end{array}$ \\
\hline $\begin{array}{l}\text { https://www.youtube.com/watch?v=pGLT } \\
\text { Jw0GSxk }\end{array}$ & $\begin{array}{l}\text { The Myth of Average }(18: 37) \\
\text { https://www.youtube.com/watch?v=4eBmyttc } \\
\text { fU4 }\end{array}$ \\
\hline $\begin{array}{l}\text { UDL Guidelines } \quad(6: 20) \\
\text { https://www.youtube.com/watch?v=rfsx3 } \\
\text { DGpv5o }\end{array}$ & $\begin{array}{l}\text { UDL Principles and Practices } \\
\text { (National Center on UD) } \\
\text { https://www.youtube.com/watch?v=pGLTJw0 }\end{array}$ \\
\hline $\begin{array}{l}\text { UDL Explained } \\
\text { (by Loudoun county Public Schools AT } \\
\text { Team) } \\
\text { https://www.youtube.com/watch?v=6P0s } \\
\text { 4qsLkt8 }\end{array}$ & $\begin{array}{l}\text { GSxk } \\
\text { William Henderson Inclusive } \\
\text { School } \\
\text { https://ww:32) } \\
\text { NRR67_osT-Q }\end{array}$ \\
\hline $\begin{array}{l}\text { Beyond } \\
\text { https://www.youtube.com/watch?v=mkBR } \\
\mathrm{m} 7-\mathrm{yJ} 30 \\
\text { Scaffolding in Education }\end{array}$ & $\begin{array}{l}\text { Disabling Segregation: Dan Habib at } \\
\text { TEDx } \\
\text { https://www.youtube.com/watch?v=izkN5vLb } \\
\text { nw8 }\end{array}$ \\
\hline $\begin{array}{l}\text { https://www.youtube.com/watch?v=ktXhl } \\
\text { PUUPDs }\end{array}$ & $\begin{array}{l}\text { Scaffolding in Education } \quad(0: 59) \\
\text { https://www.youtube.com/watch?v=ktXhIPUU } \\
\text { PDs }\end{array}$ \\
\hline $\begin{array}{l}\text { Teaching Matters: Scaffolding } \\
\text { (not captioned) } \\
\text { https://www.youtube.com/watch?v=9gNj } \\
\text { GD_W3dMm }\end{array}$ & $\begin{array}{l}\text { Teaching Matters: Scaffolding } \\
\text { (not captioned) } \\
\text { https://www.youtube.com/watch?v=9gNjGD_ } \\
\text { W3dM }\end{array}$ \\
\hline
\end{tabular}


Module contents. Following these theoretical underpinnings, each module was developed with a primary emphasis on the principles of UDL, adhering to CAST's UDL framework with fidelity. Each module presented UDL as an instructional approach that supports learners with different experiences, backgrounds, and abilities, including students with disabilities. Both modules used information from the course text, other text resources, online videos, and case studies to explore the definition, underlying premises, and applications of UDL. Figure 1 provides a list of videos used within each module to illustrate similarities and differences in module contents. Module A presented UDL as a means for accessing the general education curriculum by responding to the individual learning needs of students with disabilities (Meyer et al., 2014). More specifically, Module A reinforced the common perception that UDL is a specific strategy for meeting the needs of students with disabilities in the general education classroom or in more restrictive settings (Ralabate et al., 2012). Module A presented UDL through a view of disability as an innate and immutable characteristic requiring proprietary interventions. For example, the section on defining UDL included this from the course textbook: "'Basically, UDL ensures that students with disabilities can access the general education curriculum via curriculum modifications achieved through technology and instruction (that is, pedagogy)' (Turnbull, Turnbull, Wehmeyer, \& Shogren, 2014, p. 39)." Similarly, a discussion of the early application of UDL focused on CAST's use of technology to help students with disabilities overcome the barriers inherent in education and to "amplify areas of strength and support areas of weakness" (Meyer et al., 2014, p. 1).

Module B presented UDL as a means for creating inclusive classrooms by viewing disability as a social construction (Peters \& Reid, 2009; Valle \& Connor, 2011) and responsive to the design of learning environments. Module B comprised materials similar to those of Module A, but was supplemented with material from several sources that emphasized the relevance of UDL to creating inclusive learning spaces and communities of learners (Baglieri et al., 2011) or the application of UDL to support diverse learners in inclusive settings (Chita-Tegmark et al., 2012). For example, both Module A and Module B presented CAST's description of the three principles of UDL, but Module B also suggested the potential for UDL to "recognize and put a stop to educational practices and arrangements that position general and special educators as occupying different roles and responsibilities in the inclusive classroom/school' (Baglieri et al., p. 272)." Additionally, Module B emphasized the importance of students with disabilities as integral to the success of all learners within a community of learners (Meyer et al., 2014) and the potential for UDL to create democratic classrooms that value disability as part of diversity (Baglieri \& Shapiro, 2012). Additionally, checks for understanding and case analyses in Module B focused more on the creation of classroom community than on UDL as an instructional adaptation, which was the focus of Module A.

\section{Participants}

Seventy-seven pre-service teachers completed the study. A significant majority of participants $(78.8 \%)$ were either elementary education majors $(n=32,41.6 \%)$ or elementary and special education majors $(n=29,37.2 \%)$. Approximately three-fourths $(n=58,75.3 \%)$ of participants were in their second year in college, with nearly an additional $20 \%(n=15,19.2 \%)$ of participants being in their third year. 
An item on the BLTDQ questionnaire asked participants to indicate their level of prior experience with persons with disabilities. The distribution of participants across this factor tended to be much broader than for other demographic factors. The largest number of participants $(n=29,37.7 \%)$ responded to the prompt "I know someone with a disability, and speak with them occasionally," followed by "I have a family member with a disability (e.g., sister, father, daughter, grandmother)" $(n=21,26.9 \%)$. No participants answered affirmatively to "I have no experience with a person with a disability, either in person or in media."

\section{Data Collection}

The instrument used to answer the research questions was a questionnaire designed to rate pre-service teachers' beliefs about disability, ability, teacher-controlled instruction, student-centred instruction, and attaining standards. This instrument, the Beliefs About Learning, Teaching, and Disability Questionnaire (BLTDQ) was made available before candidates completed the intervention. A second iteration of the BLTDQ was made available after candidate completion of the intervention. This pre-post design allowed for paired comparisons of participant beliefs before and after they completed Module A or Module B on UDL.

Beliefs About Learning, Teaching, and Disability Questionnaire. The BLTDQ was adapted from the Beliefs About Learning and Teaching Questionnaire (BLTQ; Glenn, 2007; Jordan et al., 2005). The original BLTQ (Glenn, 2007) consisted of 20 items across four principal components: (a) Teacher-Controlled Instruction (TCI, four items), (b) ability (E-I, six items), (c) Student-Centred Instruction (SCI, four items), and (d) Attaining Standards (AS, six items). The items related to ability were measured on a continuum from entity to increment (E-I) and are a component of epistemological beliefs (Dweck, 1999). Glenn (2007) reported a Cronbach's alpha for the 20-item BLTQ of .840.

Pilot administration of the BLTDQ. The adapted BLTQ was the subject of a pilot study conducted prior to this study. The pilot instrument consisted of 53 items scored on a 6-point Likert-type scale. The pilot BLTDQ included items related to six dimensions: (a) beliefs about ability (seven items), (b) beliefs about teacher-controlled instruction (five items), (c) beliefs about student-centred instruction (six items), (d) beliefs about working with parents (four items), (e) beliefs about attaining standards (six items), and (f) beliefs about disability (25 items).

The items related to beliefs about disability were adapted from the pathognomonicinterventionist (P-I) dimension validated by Jordan et al. (1997) and Jordan and Stanovich (2003) and reported by Jordan et al. (2010). The P-I dimension was ascertained through a series of mixed-method studies involving interviews of approximately 100 classroom teachers (Jordan et al., 2009). The P-I items on the BLTDQ suggest beliefs along a continuum from those in which disability is seen as a fixed property of the individual (pathognomonic), to those in which disability is seen as relative to the individual's interaction with their environment (interventionist). This dimension is of importance to the study, given its direct relationship with beliefs about disability. 
Each rating on the pilot BLTDQ was scored to be consistent with the P-I construct. Thus, a rating of 1 reflected the pathognomonic end of the continuum while a rating of 6 reflected an interventionist belief, with ratings between 1 and 6 reflecting varying degrees along the continuum. Items were reverse scored, as appropriate, to be consistent with this structure.

Preliminary reliability analysis of the pilot instrument for all 53 items resulted in a Cronbach's alpha of .670. Although this reliability may be sufficient for preliminary or exploratory research (Meyers, Gamst, \& Guarino, 2013), only 30 of 48 responses were complete $(62.5 \%)$. As a result, the decision was made to limit the instrument to 30 items, removing the four items related to working with parents and only including the original 20 items from the BLTQ (Glenn, 2007) and 10 items from the P-I item set, due to their central role in this study. The ten items that constituted the final P-I set were drawn from the original 25 P-I items from the pilot administration of the BLTDQ. Corrected item total correlations were calculated, and the 10 P-I items with the highest reliability were chosen to supplement the original 20-item BLTQ.

Subsequent post hoc reliability analysis for the pilot administration with the original 20 items and the additional 10 P-I items resulted in a Cronbach's alpha of .731, a marginal improvement over the previous statistic of .670. The resulting 30-item BLTDQ constituted the final instrument for this study. Nine items on the final BLTDQ were reverse-scored to be consistent with the P-I construct (see Table 1).

Validity and reliability of the BLTDQ. The validity of the revised BLTDQ is grounded in the validity established by Glenn (2007) for the original BLTQ and the principal component analysis for the instrument. Additionally, a confirmatory factor analysis was considered for the BLTDQ to validate the factors identified in the original BLTQ, along with the added P-I subscale. However, the relatively small sample size $(n=77)$ precluded either a principal components analysis or confirmatory factor analysis (Field, 2013). Initial reliability for the administration of the BLTDQ in this study resulted in a Cronbach's alpha of .492. In accordance with recommendations by Cronbach (1951) and Field (2013), reliability calculations were completed for each subscale or factor of the instrument. A post hoc analysis was completed to determine individual subscale reliability values. The Attaining Standards subscale showed a Cronbach's alpha value of .199. However, the remaining four subscales yielded Cronbach's alpha values between .622 and $.779(\mathrm{P}-\mathrm{I}=.622$; E-I $=.743$; SCI $=.757$; $\mathrm{TCI}=.779)$. A second post hoc analysis of reliability was conducted with the four items from the Attaining Standards subscale removed, yielding a revised Cronbach's alpha value of .780 for the BLTDQ. Additionally, statistically significant results were found for the mixed ANOVA, as described below. Statistical significance, itself, has potential for confirming the reliability of statistical findings (Gelman \& Stern, 2006). 


\section{Results}

\section{Research Question 1}

Is there a significant difference in pre-service teachers' beliefs about learning, teaching, and disability between participants who completed Module A and those who completed Module B?

To answer the first research question, a mixed ANOVA was used to determine whether there was a statistically significant mean change between the pre and post total scores on the BLTDQ for either module. Tests of normality indicated that the data were normally distributed and that the assumption of homogeneity of variances was not violated. The main effect of time showed a statistically significant change in beliefs about learning, teaching, and disability between the pre-survey and post-survey, $F(1,76)=62.009, p<.001$, partial $\eta^{2}=.453$. These results suggest that approximately $45 \%(45.3 \%)$ of the change in pre-service teachers' beliefs about learning, teaching, and disability toward an interventionist perspective, as evidenced in this study, can be attributed to participating in an online training module in UDL, regardless of the way UDL was contextualized. Table 1 presents descriptive statistics, by item, for the BLTDQ pre and post administrations.

Table 1

Descriptive statistics for the BLTDQ, by Item, Pre and Post

\begin{tabular}{|c|c|c|c|c|c|}
\hline \multirow[b]{2}{*}{ Score } & \multirow[b]{2}{*}{ Item } & \multicolumn{2}{|c|}{ Pre $(N=77)$} & \multicolumn{2}{|c|}{ Post $(N=77)$} \\
\hline & & $M$ & $S D$ & $M$ & $S D$ \\
\hline AS & $\begin{array}{l}\text { 13. The more students are concerned about grades, } \\
\text { the more they learn. }{ }^{*}\end{array}$ & 4.14 & 1.29 & 4.53 & 1.15 \\
\hline AS & $\begin{array}{l}\text { 31. Giving grades is a good strategy for getting } \\
\text { students to work.* }\end{array}$ & 3.29 & 1.17 & 3.81 & 1.15 \\
\hline AS & $\begin{array}{l}\text { 33. All of my students will do well, as long as they } \\
\text { work hard. }\end{array}$ & 4.91 & 0.96 & 4.91 & 0.92 \\
\hline AS & $\begin{array}{l}\text { 35. Students who produce correct answers have a } \\
\text { good understanding of the core concepts. }\end{array}$ & 3.43 & 1.27 & 3.40 & 1.07 \\
\hline $\mathrm{EI}$ & $\begin{array}{l}\text { 16. The ability to learn is something people have a } \\
\text { certain amount of and there isn't much they can } \\
\text { do to change it.* }\end{array}$ & 4.84 & 1.18 & 5.08 & 1.12 \\
\hline $\mathrm{EI}$ & $\begin{array}{l}\text { 18. The ability to learn is something that remains } \\
\text { fixed throughout life. }{ }^{*}\end{array}$ & 4.04 & 1.66 & 4.18 & 1.68 \\
\hline EI & $\begin{array}{l}\text { 20. There isn't much I can do about how much ability } \\
\text { I have in mathematics, science and language } \\
\text { arts. }^{*}\end{array}$ & 4.90 & 1.12 & 5.06 & 1.07 \\
\hline El & $\begin{array}{l}\text { 21. There will always be some students who simply } \\
\text { don't get it no matter what I do..* }\end{array}$ & 4.26 & 1.31 & 4.57 & 1.30 \\
\hline $\mathrm{PI}$ & $\begin{array}{l}\text { 10. I am responsible for teaching every student in } \\
\text { my class, including those with disabilities. }\end{array}$ & 5.82 & 0.53 & 5.84 & 0.43 \\
\hline $\mathrm{PI}$ & $\begin{array}{l}\text { 12. Teachers should plan to spend time with their } \\
\text { students with learning disabilities while the rest } \\
\text { of the class is working on a task. }\end{array}$ & 2.78 & 1.12 & 3.18 & 1.20 \\
\hline $\mathrm{PI}$ & $\begin{array}{l}\text { 14. In-class student work provides the most } \\
\text { information about student progress. }\end{array}$ & 3.92 & 0.96 & 3.87 & 1.24 \\
\hline
\end{tabular}


Table 1, continued

\begin{tabular}{|c|c|c|c|c|c|}
\hline $\mathrm{PI}$ & $\begin{array}{l}\text { 15. Observations and assessments of students with } \\
\text { disabilities provide useful information for } \\
\text { planning instruction for the entire class. }\end{array}$ & 3.96 & 1.39 & 4.00 & 1.31 \\
\hline PI & $\begin{array}{l}\text { 17. I am confident that I will be able to get through to } \\
\text { even the most disabled student. }\end{array}$ & 4.68 & 1.08 & 4.97 & 1.10 \\
\hline PI & $\begin{array}{l}\text { 19. Teachers should spend as much time with their } \\
\text { struggling students as they do with their typically } \\
\text { achieving classmates. }\end{array}$ & 4.55 & 1.40 & 4.78 & 1.33 \\
\hline PI & $\begin{array}{l}\text { 24. In fairness to other students, students who have } \\
\text { a disability should not get grades higher than a } \\
\text { minimum pass. }{ }^{*}\end{array}$ & 5.09 & 1.27 & 5.07 & 1.44 \\
\hline PI & $\begin{array}{l}\text { 29. I will hold the same high expectations for all } \\
\text { students in my class, }\end{array}$ & 4.56 & 1.18 & 4.83 & 1.16 \\
\hline PI & $\begin{array}{l}\text { 34. Only students who are working on grade level } \\
\text { curriculum should be in my class.* }\end{array}$ & 4.69 & 1.21 & 5.05 & 1.06 \\
\hline PI & $\begin{array}{l}\text { 36. The learning patterns and history of a student } \\
\text { who is not achieving need to be thoroughly } \\
\text { evaluated by the teacher before the student is } \\
\text { referred }\end{array}$ & 4.53 & 1.21 & 4.66 & 1.23 \\
\hline $\mathrm{SCl}$ & $\begin{array}{l}\text { 23. To assess students' understanding of a core } \\
\text { concept, it is important to observe and listen to } \\
\text { them as they work. }\end{array}$ & 5.26 & 0.82 & 5.13 & 1.07 \\
\hline $\mathrm{SCl}$ & $\begin{array}{l}\text { 25. Good teachers give students choices in their } \\
\text { learning tasks. }\end{array}$ & 4.66 & 1.01 & 5.16 & 1.19 \\
\hline $\mathrm{SCl}$ & $\begin{array}{l}\text { 26. In core subjects, students should construct their } \\
\text { own examples. }\end{array}$ & 4.39 & 1.15 & 4.79 & 0.98 \\
\hline $\mathrm{SCl}$ & $\begin{array}{l}\text { 27. Good instruction relates learning material to } \\
\text { things students are interested in outside of } \\
\text { school. }\end{array}$ & 5.21 & 0.95 & 5.36 & 0.86 \\
\hline $\mathrm{SCl}$ & $\begin{array}{l}\text { 28. It doesn't matter whether students get the right } \\
\text { or wrong answer as long as they understand the } \\
\text { concepts inherent in the problem. }\end{array}$ & 3.86 & 1.04 & 4.06 & 1.08 \\
\hline $\mathrm{SCl}$ & $\begin{array}{l}\text { 30. Concerns about getting the right answer are } \\
\text { likely to interfere with concept development and } \\
\text { learning. }\end{array}$ & 4.56 & 1.01 & 4.51 & 1.21 \\
\hline $\mathrm{TCl}$ & $\begin{array}{l}\text { 7. Students should rely on the teacher to evaluate } \\
\text { their work. }\end{array}$ & 2.66 & 1.07 & 3.18 & 1.19 \\
\hline $\mathrm{TCl}$ & $\begin{array}{l}\text { 8. It is important for students to complete } \\
\text { assignments exactly as the teacher planned. }\end{array}$ & 2.70 & 1.18 & 3.84 & 1.24 \\
\hline $\mathrm{TCl}$ & $\begin{array}{l}\text { 9. In every class, I find students to whom I cannot } \\
\text { teach core concepts. }{ }^{*}\end{array}$ & 4.30 & 1.06 & 4.53 & 1.20 \\
\hline $\mathrm{TCl}$ & $\begin{array}{l}\text { 11. It is important for teachers, not students, to direct } \\
\text { the flow of a lesson. }\end{array}$ & 2.96 & 1.32 & 3.62 & 1.35 \\
\hline $\mathrm{TCl}$ & $\begin{array}{l}\text { 22. Students cannot be counted upon to evaluate } \\
\text { their own work. }\end{array}$ & 4.45 & 1.18 & 4.48 & 1.12 \\
\hline $\mathrm{TCl}$ & $\begin{array}{l}\text { 32. It is important for teachers to have control over } \\
\text { lessons. }\end{array}$ & 2.04 & 0.91 & 2.65 & 1.30 \\
\hline
\end{tabular}

Note: Item numbering begins after six demographic items in the questionnaire not reported in this table. An $\left(^{*}\right)$ indicates an item that was reverse scored. 
However, results of this analysis revealed that no main effect occurred for either Module A or Module B, $F(1,76)=.007, p=.933$, partial $\eta^{2}=0$. In other words, the significance of the change in scores on the BLTDQ could not be attributed to either module specifically. Table 2 presents the average means and standard deviations of responses on the BLTDQ for both modules, pre- and post-survey.

\section{Table 2}

\section{Descriptive Statistics for the BLTDQ, by Module, Pre-Post Survey}

\begin{tabular}{ccccccc}
\hline & \multicolumn{3}{c}{ Pre } & \multicolumn{3}{c}{ Post } \\
\cline { 2 - 7 } Module & $\boldsymbol{n}$ & $\boldsymbol{M}$ & $\boldsymbol{S D}$ & $\boldsymbol{n}$ & $\boldsymbol{M}$ & $\boldsymbol{S D}$ \\
\hline Module A & 37 & 125.88 & 9.12 & 37 & 132.89 & 11.59 \\
Module B & 40 & 125.03 & 8.15 & 40 & 133.36 & 12.56 \\
\hline
\end{tabular}

A mixed ANOVA procedure was also used to determine whether there was a statistically significant mean change in beliefs between the pre and post scores on each of the subscales of the BLTDQ, as well as the three subscales combined. . Each mixed ANOVA procedure found a statistically significant main effect for time, ranging from teacher-controlled instruction, $F(1,75)=57.259, p<.001$, partial $\eta^{2}=.433$, to studentcentred instruction, $F(1,75)=5.937, p<.05$, partial $\eta^{2}=.073$, and entity-increment, $F(1,75)=5.931, p<.05$, partial $\eta^{2}=.073$. The main effect for time on the BLTQ, overall, suggested that approximately $37 \%$ (37.1\%) of the change in pre-service teachers' beliefs on the BLTQ, toward an interventionist belief about disability, can be attributed to participation in a training module on UDL, $F(1,75)=44.270, p<.001$, partial $\eta^{2}=.371$. The mixed ANOVA for the P-I subscale was of particular interest and suggested that approximately $18 \%(18.2 \%)$ of the change in pre-service teachers' beliefs about disability toward an interventionist perspective can be attributed to participating in a training module on UDL $\left(F(1,75)=16.727, p<.001\right.$, partial $\left.\eta^{2}=.182\right)$. Tables $3,4,5$, and 6 present the average means and standard deviations of responses for the Teacher Controlled, P-I, Student Centred, and E-I subscales of the BLTDQ, respectively for both modules from the pre-survey to the post-survey.

Table 3

Descriptive Statistics for the TCI Subscale of the BLTDQ, by Module, Pre-Post Survey

\begin{tabular}{lcccccc}
\hline & \multicolumn{4}{c}{ Pre } & \multicolumn{3}{c}{ Post } \\
\cline { 2 - 7 } \multicolumn{1}{c}{ Module } & $\boldsymbol{n}$ & $\boldsymbol{M}$ & $\boldsymbol{S D}$ & $\boldsymbol{n}$ & $\boldsymbol{M}$ & $\boldsymbol{S D}$ \\
\hline Module A & 37 & 19.09 & 4.27 & 37 & 22.22 & 4.01 \\
Module B & 40 & 19.15 & 3.93 & 40 & 22.40 & 4.86 \\
\hline
\end{tabular}


Table 4

Descriptive Statistics for the P-I subscale of the BLTDQ, by Module, Pre-Post Survey

\begin{tabular}{rcccccc}
\hline & \multicolumn{3}{c}{ Pre } & \multicolumn{3}{c}{ Post } \\
\cline { 2 - 7 } Module & $\boldsymbol{n}$ & $\boldsymbol{M}$ & $\boldsymbol{S D}$ & $\boldsymbol{n}$ & $\boldsymbol{M}$ & $\boldsymbol{S D}$ \\
\hline Module A & 37 & 44.71 & 4.53 & 37 & 45.00 & 5.09 \\
Module B & 40 & 44.43 & 3.69 & 40 & 46.51 & 4.68 \\
\hline
\end{tabular}

Table 5

Descriptive Statistics for the E-I subscale of the BLTDQ, by Module, Pre-Post Survey

\begin{tabular}{ccccccc}
\hline \multirow{2}{*}{ Module } & \multicolumn{4}{c}{ Pre } & \multicolumn{3}{c}{ Post } \\
\cline { 2 - 7 } & $\boldsymbol{n}$ & $\boldsymbol{M}$ & $\boldsymbol{S D}$ & $\boldsymbol{n}$ & $\boldsymbol{M}$ & $\boldsymbol{S D}$ \\
\hline Module A & 37 & 18.50 & 3.13 & 37 & 19.05 & 3.23 \\
Module B & 40 & 17.58 & 3.73 & 40 & 18.75 & 3.91 \\
\hline
\end{tabular}

Table 6

Descriptive Statistics for the SCI subscale of the BLTDQ, by Module, Pre-Post Survey

\begin{tabular}{ccccccc}
\hline \multirow{2}{*}{ Module } & \multicolumn{4}{c}{ Pre } & \multicolumn{3}{c}{ Post } \\
\cline { 2 - 7 } & $\boldsymbol{n}$ & $\boldsymbol{M}$ & $\boldsymbol{S D}$ & $\boldsymbol{n}$ & $\boldsymbol{M}$ & $\boldsymbol{S D}$ \\
\hline Module A & 37 & 27.89 & 3.78 & 37 & 28.81 & 4.29 \\
Module B & 40 & 27.98 & 3.56 & 40 & 29.21 & 3.59 \\
\hline
\end{tabular}

As with the mixed ANOVA for the overall BLTDQ, no interaction was found for either Module A or Module B within each of the instrument subscales. In other words, the mixed ANOVA procedure did not indicate that the change in scores for the Teacher Controlled, P-I, E-I, or Student Centred subscales of the BLTDQ could be attributed to either module specifically. The findings of this mixed ANOVA reflect an overall change in beliefs among participants toward an interventionist perspective for the BLTDQ and each of its subscales, following completion of either module on UDL.

\section{Research Question 2}

Is there a relationship between pre-service teachers' epistemological beliefs and their beliefs about disability?

A Pearson's product-moment correlation analysis was conducted to determine whether a significant relationship existed between participants' epistemological beliefs and their beliefs about disability. Epistemological beliefs were represented by a combination of average total scores for the Teacher Controlled, Student Centred, and E-I 
items following the intervention. Participants' beliefs about disability were represented by average total scores on the P-I items following the intervention. Results of the correlation analysis (see Table 7) found no relationship between beliefs about disability and epistemological beliefs prior to the intervention $(R=0.163, p=0.157)$. However, subsequent to participants completing the training on UDL, analyses indicated a moderate, positive significant correlation $(R=.478, p<.001)$ between epistemological beliefs and beliefs about disability. Further, a correlation analysis was conducted to determine the relationship between beliefs about disability and the overall construct of the BLTDQ. The correlation between the average total scores on the P-I items prior to completing the modules and the average total scores on the BLTDQ demonstrated a moderate, positive correlation $(R=.616, p<.001)$. Following the completion of the modules, the correlation between beliefs about disability and epistemological beliefs demonstrated a strong, positive correlation $(R=.774, p<.001)$.

\section{Table 7}

Pearson's Product Moment Correlations for Demographic Factors, P-I scores, and Combined TCI, SCI, and E-I Scores

\begin{tabular}{|c|c|c|c|c|c|c|}
\hline & $\begin{array}{c}\text { P-I } \\
\text { (Pre) }\end{array}$ & $\begin{array}{c}\text { P-I } \\
\text { (Post) }\end{array}$ & $\begin{array}{l}\text { BLTQ } \\
\text { (Pre) }\end{array}$ & $\begin{array}{l}\text { BLTQ } \\
\text { (Post) }\end{array}$ & $\begin{array}{c}\text { BLTDQ } \\
\text { (Pre) }\end{array}$ & $\begin{array}{c}\text { BLTDQ } \\
\text { (Post) }\end{array}$ \\
\hline $\begin{array}{l}\text { P-I } \\
\text { (Pre) }\end{array}$ & - & $\begin{array}{l}0.688 \\
(0)^{\star \star \star}\end{array}$ & $\begin{array}{c}0.163 \\
(0.157)\end{array}$ & $\begin{array}{c}0.250 \\
(.028)^{\star}\end{array}$ & $\begin{array}{l}0.616 \\
(0)^{\star \star *}\end{array}$ & $\begin{array}{l}0.487 \\
(0)^{\star * *}\end{array}$ \\
\hline $\begin{array}{l}\text { P-I } \\
\text { (Post) }\end{array}$ & & - & $\begin{array}{c}0.314 \\
(0.005)^{\star *}\end{array}$ & $\begin{array}{l}0.478 \\
(0)^{\star * *}\end{array}$ & $\begin{array}{l}0.616 \\
(0)^{\star \star *}\end{array}$ & $\begin{array}{l}0.774 \\
(0)^{\star * *}\end{array}$ \\
\hline $\begin{array}{l}\text { BLTQ } \\
\text { (Pre) }\end{array}$ & & & - & $\begin{array}{l}0.571 \\
(0)^{\star \star \star}\end{array}$ & $\begin{array}{l}0.845 \\
(0)^{\star \star *}\end{array}$ & $\begin{array}{l}0.515 \\
(0)^{\star * \star}\end{array}$ \\
\hline $\begin{array}{l}\text { BLTQ } \\
\text { (Post) }\end{array}$ & & & & - & $\begin{array}{l}0.617 \\
(0)^{\star \star *}\end{array}$ & $\begin{array}{l}0.910 \\
(0)^{\star \star \star}\end{array}$ \\
\hline $\begin{array}{l}\text { BLTDQ } \\
\text { (Pre) }\end{array}$ & & & & & - & $\begin{array}{l}0.706 \\
(0)^{\star \star *}\end{array}$ \\
\hline $\begin{array}{l}\text { BLTDQ } \\
\text { (Post) }\end{array}$ & & & & & & - \\
\hline \multicolumn{7}{|c|}{$\begin{array}{l}\text { Note. P-I (Pre) = average total scores for P-I items on pre-survey; P-I (Post) }=\text { averag } \\
\text { total scores for P-I items on post-survey; BLTQ (Pre) }=\text { average total scores for TC } \\
\text { SCI, and E-I, combined, on the pre-survey; BLTQ (Post) = average total scores for TC } \\
\text { SCI, and E-I, combined, on the post-survey; BLTDQ (Pre) = average total scores o } \\
\text { the overall BLTDQ pre-survey; BLTDQ (Post) }=\text { average total scores on the overa } \\
\text { BLTDQ post-survey. }{ }^{*} p<0.05 .{ }^{*} p<0.01 .{ }^{* * *} p<0.001\end{array}$} \\
\hline
\end{tabular}

\section{Discussion and Recommendations}

\section{Research Question One}

Analysis of the results from the BLTDQ illustrated a statistically significant change in beliefs about learning, teaching, and disability pre- and post-intervention, as noted in the Results section. The mixed ANOVA found no interaction between time and intervention, however, suggesting that there was no significant difference in belief change between participants who completed Module A and those who completed Module 
B. The interpretation of these findings supports the position that UDL is an important element of teacher preparation for meeting the needs of students with disabilities (Brownell, Sindelar, Kiely, \& Danielson, 2010; Israel, Ribuffo, \& Smith, 2014).

Jordan et al. (2010) reported that teacher practices supporting student-centred instruction and incremental beliefs in learning correlate with interventionist beliefs about disability. The flexibility that is characteristic of the UDL framework allows for student autonomy and self-regulation (Hall, Vue, Strangman, \& Meyer, 2004). Similarly, the underlying premise of UDL suggests that "all participants in any educational environment should be learning, growing, and improving" (Meyer et al., 2014, p. 15), reflecting the inherent incremental view of learning in the UDL framework.

Training in UDL, as presented in Module A, appears to promote practices that support students with disabilities by adapting instruction to make the curriculum more usable. Such practices are undeniably helpful to students with disabilities, regardless of their placement in general or special education classrooms (Meyer et al., 2014). Numerous studies, however, have examined general and special education pre-service and in-service teachers' beliefs about students with disabilities and inclusion (e.g., Cook \& Cameron, 2010; Jordan et al., 2009; Jordan \& Stanovich, 2003; McHatton \& Parker, 2013). These studies suggest that placement in the general education classroom is not necessarily an impetus for facilitating more positive beliefs about disability. Similarly, no research to date has supported the premise that UDL, when applied as an approach to creating inclusive learning spaces that promote community and acceptance of difference, has a positive effect on beliefs about disability. The findings of this study offer a hopeful response to this gap in the literature by demonstrating the potential for such training to shift pre-service teachers' beliefs about disability toward the interventionist end of the P-I continuum, though such changes may initially be marginal.

Thus, these findings support the work of Jordan and colleagues in the assertion that that training in UDL, regardless of its approach to supporting students with and without disabilities, may lead to more interventionist beliefs about learning, teaching, and disability. Recalling that interventionist beliefs are associated with teaching practices that are more supportive of students with disabilities in general education classrooms (Jordan et al., 2010; Jordan et al., 1997; Jordan \& Stanovich, 2003), teacher preparation programs are called upon to consider the value of training in UDL as a more substantial element of their curricula. In the United States, while a high percentage of teacher preparation programs that receive federal Teacher Quality Enhancement grant funding do include training in UDL (Vitelli, 2015), the implications of this study highlight the value of training in UDL for all teacher preparation programs.

\section{Research Question Two}

Silverman (2007) found that high-level epistemological beliefs demonstrated a statistically significant correlation with beliefs about inclusion. The measure of beliefs about inclusion used in Silverman's study, the Opinions Relative to Integration of Students with Disabilities scale (Antonak \& Larrivee, 1995), did not directly address beliefs about disability, but did contain items relative to teachers' academic and behavioural expectations of students with disabilities (Silverman, 2007). Similarly, Glenn 
(2007) found that teachers who held more incremental beliefs about ability also tended to hold more interventionist beliefs about disability and their roles in working with students with disabilities. The moderate to strong relationships between pre-service teachers' beliefs about disability and epistemological beliefs identified in this study support and extend the findings of Silverman and of Glenn.

The positive relationship between high-level epistemological beliefs and interventionist beliefs about disability is noteworthy for teacher preparation programs, given its implication for teacher practice. A continuing challenge that teacher preparation programs face is the predominance among pre-service teachers of instructional beliefs that favour teacher-controlled instruction (Domovic, Vlasta, \& Bouillet, 2017). Such beliefs tend to allow for little flexibility in the ways that students might engage with learning, suggesting an underlying notion that students' potential to learn is fixed. Teacher preparation programs might mitigate beliefs favouring teacher-controlled instruction by emphasizing the potential for UDL to reveal student ability in unexpected ways and to focus on complex and effortful notions of learning.

\section{Limitations}

These findings may lack generalizability due to the relatively small sample of preservice teachers from a single institution in the southwestern United States. However, findings of this study are like those reported in other studies of pre-service teachers' beliefs (e.g., Ajuwon et al., 2012; Forlin \& Chambers, 2011). For example, Ajuwon et al. reported that the attitudes of 67 pre-service teachers toward teaching students with disabilities was significantly more positive after completing an introductory special education course.

A second limitation was the limited duration of the intervention. The intervention in this study consisted of a short-term online training module. The short duration of the intervention may have muted the results of the data, reflecting the lack of interaction between the two intervention modules. However, studies by Gill, Ashton, and Algina (2004) and Kienhues, Bromme, and Stahl (2008) suggested that even short-term interventions can impact beliefs. Moreover, the lack of interaction between the different modules and pre-post survey results may reflect the sensitive nature of differences between the two ends of the P-I continuum. The differences between the content in Module A and Module B were designed to present the core elements of the UDL framework, as outlined by CAST, while emphasizing different philosophic and epistemological underpinnings. As noted by Pajares (1992) and Schraw (2013), measuring beliefs is difficult, and to do so, one must infer such beliefs (Bandura, 1977). A deeper differentiation between the content within the modules may have resulted in a more substantial interaction between the two modules.

\section{Conclusion}

Beliefs about ability and disability impact teachers' interactions with their students (Jordan et al., 2010). This study demonstrated the impact that training in UDL might have on pre-service teachers' beliefs toward an interventionist view of disability. Implications of this research highlight the important role that deliberate training in UDL can have in 
preparing future educators for increasingly inclusive classrooms that honour students with disabilities as citizens in a democratic community of learners.

\section{References}

Abell, M. M., Jung, E., \& Taylor, M. (2011). Students' perceptions of classroom instructional environments in the context of Universal Design for Learning. Learning Environments Research, 14, 171-185. doi:10.1007/s10984-011-9090-2

Ainscow, M., Dyson, A., \& Weiner, S. (2012). From exclusion to inclusion. A review of international literature on ways of responding to students with special needs in schools. Retrieved from the ERIC database (Doc. ED546818), https://eric.ed.gov

Ajuwon, P. M., Lechtenberger, D., Griffin-Shirley, N., Sokolosky, S., Shou, L., \& Mullins, F. E. (2012). General education preservice teachers' perceptions of including students with disabilities in their classroom. International Journal of Special Education, 27, 100-107.

Alghazo, E. M., Dodeen, H., \& Algaryouti, I. A. (2003). Attitudes of pre-service teachers towards persons with disabilities: Predictions for the success of inclusion. The College Student Journal, 37, 515-522.

Antonak, R. F., \& Larrivee, B. (1995). Psychometric analysis and revision of the Opinions Relative to Mainstreaming scale. Exceptional Children, 62, 139-149.

Artiles, A. J., \& Kozleski, E. B. (2016). Inclusive education's promises and trajectories: Critical notes about future research on a venerable idea. Education Policy Analysis Archives, 24(43). doi:10.14507/epaa.24.1919

Baglieri, S. (2017). Disability studies in the inclusive classroom: Critical practices for embracing diversity in education. New York, NY: Routledge.

Baglieri, S., \& Shapiro, A. (2012). Disability studies in the inclusive classroom: Critical practices for creating least restrictive attitudes. New York, NY: Routledge.

Baglieri, S., Valle, J. W., Connor, D. J., \& Gallagher, D. J. (2011). Disability studies in education: The need for a plurality of perspectives on disability. Remedial and Special Education, 32(4), 267-278. doi:10.1177/0741932510362200

Bandura, A. (1977). Self-efficacy: Toward a unifying theory of behavioral change. Psychological Review, 84, 191-215.

Basham, J. D., Israel, M., Graden, J., Poth, R., \& Winston, M. (2010). A comprehensive approach to RTI: Embedding universal design for learning and technology. Learning Disability Quarterly, 33(4), 243-255.

Capp, M. J. (2017). The effectiveness of universal design for learning: A meta-analysis of literature between 2013 and 2016. International Journal of Inclusive Education, 21, 791-807.

Chita-Tegmark, M., Gravel, J. W., Serpa, M. B., Domings, Y., \& Rose, D. H. (2012). Using the universal design for learning framework to support culturally diverse learners. Journal of Education, 192(1), 17-22.

Cook, B. G. (2002). Inclusive attitudes, strengths, and weaknesses of pre-service general educators enrolled in a curriculum infusion teacher preparation program. Teaching and Teacher Education, 25(3), 262-277. doi:10.1177/088840640202500306

Cook, B. G., \& Cameron, D. L. (2010). Inclusive teachers' concern and rejection toward their students: Investigating the validity of ratings and comparing student groups. Remedial and Special Education, 31, 67-76. doi:10.1177/0741932508324402

Courey, S. J., Tappe, P., Siker, J., \& LePage, P. (2013). Improved lesson planning with Universal Design for Learning (UDL). Teacher Education and Special Education, 36, 7-27. 
Crockett, J. B. (2014). Reflections on the concept of the Least Restrictive Environment in special education. In B. Cook, M. Tankersley, \& T. Landrum, (Eds.), Advances in Learning and Behavioral Disabilities: Vol 27. Special education past, present, and future perspectives from the field (pp. 39-61). London, UK: Emerald.

Cronbach, L. J. (1951). Coefficient alpha and the internal structure of tests. Psychometrika, 16, 297-334.

Danforth, S., Taff, S., \& Ferguson, P. M. (2006). Place, profession, and program in the history of special education curriculum. In E. A. Brantlinger (Ed.), Who benefits from special education: Remediating (fixing) other people's children (pp. 1-25). Mahwah, NJ: L. Erlbaum.

Domovic, V., Vlasta, V. V., \& Bouillet, D. (2017). Student teachers' beliefs about the teacher's role in inclusive education. European Journal of Special Needs Education, 32, 175-190. doi:10.1080/08856257.2016.1194571

Dunst, C. J., \& Bruder, M. B. (2013). Preservice professional preparation and teachers' self-efficacy appraisals of natural environment and inclusion practices. Teacher Education and Special Education, 37(2), 121-132. doi:10.1177/0888406413505873

Edyburn, D. L. (2010). Would you know Universal Design for Learning if you saw it? Ten propositions for new directions for the second decade of UDL. Learning Disability Quarterly, $33,33-41$.

Field, A. (2013). Discovering statistics using IBM SPSS statistics (4th ed.). London, UK: Sage.

Forlin, C., \& Chambers, D. (2011). Teacher preparation for inclusive education: Increasing knowledge but raising concerns. Asia-Pacific Journal of Teacher Education, 39, 17-32. doi:10.1080/1359866X.2010.540850

Gabel, S. L. (2006). Applying disability theory in educational policy: NIDRR's "new paradigm of disability" as a cautionary tale. In S. Danforth \& S. L. Gabel (Eds.), Vital questions facing disability studies in education (pp. 179-200). New York, NY: Peter Lang.

Gelman, A., \& Stern, H. S. (2006). The difference between "significant" and "not significant" is not itself statistically significant. American Statistician, 60, 328-331. doi:10.1198/000313006X152649

Gill, M. G., Ashton, P. T., \& Algina, J. (2004). Changing preservice teachers' epistemological beliefs about teaching and learning in mathematics: An intervention study. Contemporary Educational Psychology, 29, 164-185. doi:10.1016/j.cedpsych.2004.01.003

Glenn, C. (2007). The impact of teachers' epistemological beliefs and their beliefs about disability on their teaching practices in inclusive classrooms (Unpublished Ph.D. dissertation). University of Toronto, Toronto, ON.

Glenn, C. (2018). The measurement of teacher's beliefs about ability: Development of the Beliefs About Learning and Teaching Questionnaire. Exceptionality Education International, 28(3), $51-66$.

Hall, T., Vue, G., Strangman, N., \& Meyer, A. (2004). Differentiated instruction and implications for UDL implementation. Wakefield, MA: National Center on Accessing the General Curriculum. Retrieved from http://aem.cast.org/about/publications/2003/ncac-differentiatedinstruction-udl.html

Higher Education Opportunity Act, 20 U.S.C. § 1001 (2008). Public Law 110-315, Section 103, a(24).

Israel, M., Ribuffo, C., \& Smith, S. (2014). Universal Design for Learning: Recommendations for teacher preparation and professional development (Document No. IC-7). Retrieved from University of Florida, Collaboration for Effective Educator, Development, Accountability, and Reform Center, http://ceedar.education.ufl.edu/tools/innovation-configurations/

Jordan, A. (2018a). The Supporting Effective Teaching project: 1. Factors influencing student success in inclusive elementary classrooms. Exceptionality Education International, 28(3), 10-27. 
Jordan, A. (2018b). The Supporting Effective Teaching project: 2. The measures. Exceptionality Education International, 28(3), 28-50.

Jordan, A., Glenn, C., \& McGhie-Richmond, D. (2010). The Supporting Effective Teaching (SET) project: The relationship of inclusive teaching practices to teachers' beliefs about disability and ability, and about their roles as teachers. Teaching and Teacher Education, 26(2), 259266. doi:10.1016/j.tate.2009.03.005

Jordan, A., Lindsay, L., \& Stanovich, P. (1997). Classroom teachers' instructional interactions with students who are exceptional, at risk, and typically achieving. Remedial and Special Education, 18(2), 82-93. doi:10.1177/074193259701800202

Jordan, A., Schwartz, E., \& McGhie-Richmond, D. (2009). Preparing teachers for inclusive education. Teaching and Teacher Education, 25, 535-542. doi:10.1016/j.tate.2009.0

Jordan, A., \& Stanovich, P. (2003). Teachers' personal epistemological beliefs about students with disabilities as indicators of effective teaching practices. Journal of Research in Special Educational Needs, 3, 1-14. doi:10.1111/j.1471-3802.2003.00184.x

Jordan, A., Washington, D., Schwartz, E., \& Ahmed, Q. (2005, May). Effective teaching in inclusive classrooms. Paper presented at the Canadian Society for Studies in Education, London, Ontario.

Katz, J., \& Sokal, L. (2016). Universal Design for Learning as a bridge to inclusion: A qualitative report of student voices. International Journal of Whole Schooling, 12(2), 36-63.

Kienhues, D., Bromme, R., \& Stahl, E. (2008). Changing epistemological beliefs: The unexpected impact of a short-term intervention. British Journal of Educational Psychology, 78, 545-565.

McHatton, P. A., \& Parker, A. (2013). Purposeful preparation: Longitudinally exploring inclusion attitudes of general and special education pre-service teachers. Teacher Education and Special Education, 36(3), 186-203. doi:10.1177/0888406413491611

Meyer, A., Rose, D. H., \& Gordon, D. (2014). Universal Design for Learning: Theory and practice. Wakefield, MA: CAST.

Meyers, L. S., Gamst, G. C., \& Guarino, A. J. (2013). Performing data analysis using IBM SPSS. Hoboken, NJ: Wiley.

Mitchell, D. T., Snyder, S. L., \& Ware, L. (2014). "Every child left behind": Curricular cripistemologies and the crip/queer art of failure. Journal of Literary \& Cultural Disability Studies, 8, 295-313. doi:10.3828/jlcds.2014.24

Pajares, M. F. (1992). Teachers' beliefs and educational research: Cleaning up a messy construct. Review of Educational Research, 62(3), 307-332. doi:10.3102/00346543062

Peters, S., \& Reid, K. (2009). Resistance and discursive practice: Promoting advocacy in teacher undergraduate and graduate programmes. Teaching and Teacher Education, 25, 551-558.

Ralabate, P., Hehir, T., Dodd, E., Grindal, T., Vue, G., Eidelman, H., \& Carlisle, A. (2012). Universal Design for Learning (UDL): Initiatives on the move: Understanding the impact of the race to the top and ARRA funding on the promotion of universal design for learning. Wakefield, MA: National Center on Universal Design for Learning.

Richardson, V. (1996). The role of attitudes and beliefs in learning to teach. In J. Sikula (Ed.), Handbook of research on teacher education (2nd ed., pp. 102-119). New York, NY: MacMillan.

Routel, C. (2013). Special education teacher preparation and student outcomes: How the infusion of disability studies can create change. PowerPlay, 5(1), 392-430. 
Schraw, G. (2013). Conceptual integration and measurement of ontological and epistemological beliefs in educational research. International Scholarly Review Notice, 2013, Article ID 327680. Retrieved from http://www.hindawi.com/journals/isrn/2013/327680/

Scruggs, T. E., \& Mastropieri, M. A. (1996). Teacher perceptions of mainstreaming/inclusion, 19581995: A research synthesis. Exceptional Children, 63(1), 59-74.

Sheehy, K., Budiyanto, H. K., \& Rofiah, K. (2017). Indonesian teachers' epistemological beliefs and inclusive education. Journal of Intellectual Disabilities. Advance online publication. doi: $10.1177 / 1744629517717613$

Silverman, J. C. (2007). Epistemological beliefs and attitudes toward inclusion in pre-service teachers. Teacher Education and Special Education, 30(1), 42-51. doi:10.1177/088840640703000105

Spooner, F., Baker, J. N., Harris, A. A., Ahlgrim-Delzell, L., \& Browder, D. M. (2007). Effects of training in universal design for learning on lesson plan development. Remedial and Special Education, 28, 108-116. doi:10.1177/07419325070280020101

Stanovich, P., \& Jordan, A. (1998). Canadian teachers' and principals' beliefs about inclusive education as predictors of effective teaching in heterogeneous classrooms. The Elementary School Journal, 98, 221-238.

Turnbull, A., Turnbull, R., Wehmeyer, M. L., \& Shogren, K. A. (2014). Exceptional lives: Special education in today's schools (7th ed.). Upper Saddle River, NJ: Merrill.

Turnbull, A., Turnbull, R., Wehmeyer, M. L., \& Shogren, K. A. (2016). Exceptional lives: Special education in today's schools (8th ed.). Upper Saddle River, NJ: Merrill.

U.S. Department of Education. (2007). 29th annual report to Congress on the implementation of the Individuals with Disabilities Education Act. Washington, DC: Author.

U.S. Department of Education. (2017). 39th annual report to Congress on the implementation of the Individuals with Disabilities Education Act. Washington, DC: Author.

Valle, J. W., \& Connor, D. J. (2011). Rethinking disability: A disability studies approach to inclusive practices. New York, NY: McGraw Hill.

Wilson, J. D. (2017). Reimagining disability and inclusive education through Universal Design for Learning. Disability Studies Quarterly, 37(2). doi:10.18061/dsq.v37i2.5417

\section{Authors' Note}

Correspondence concerning this article should be addressed to Christopher S. Lanterman, Department of Educational Specialties, Northern Arizona University, PO Box 5774, Flagstaff, AZ, 86011, U.S.A. Email: Chris.Lanterman@nau.edu 